\title{
Collaborative Writing Against the Ability to Write Explanatory Texts in Discipline Learning
}

\author{
Melisa $^{1}$, Y Pebriani ${ }^{2}$, R L Tiawati ${ }^{3}$, R Satini $^{4}$, S Dwinitia $^{5}$, T Helda $^{6}$ \\ 1,2,3,4,5,6Pendidikan Bahasa dan Sastra Indonesia STKIP PGRI Sumatera Barat \\ \{melisathanjung@gmail.com¹, yulia@stkip-pgri-sumbar.ac.id², ria@stkip-pgri-sumbar.ac.id ${ }^{3}$, \\ refa@stkip-pgri-sumbar.ac.id ${ }^{4}$, suci@stkip-pgri-sumbar.ac.id ${ }^{5}$, trisna@stkip-pgri-sumbar.ac.id $\left.{ }^{6}\right\}$
}

\begin{abstract}
The ability of students to write explanatory texts is still low. First, students tend not to pay attention to the structure and language of the explanatory text in writing. Secondly, students are weak in writing explanatory texts because students have difficulty communicating the material into written form. Third, it is difficult for students to develop ideas in written form. Fourth, students are still not able to make effective sentences and use punctuation that is not right. The results of data processing on the ability to write explanatory texts First, the ability to write explanatory texts before using students' collaborative writing technique is 54.46. Second, the ability to write explanatory texts after using collaborative writing techniques. Third, there is a significant influence on the use of collaborative writing techniques on the ability to write explanatory text of students. This is evidenced by the results of research that show that the value of $\mathrm{t}_{\text {count }}(5.74)>\mathrm{t}_{\text {table }}(1.71)$, so that $\mathrm{H}_{0}$ is rejected and $\mathrm{H}_{1}$ is accepted.
\end{abstract}

Keywords: Writing, Explanatory Text, Collaborative Writing

\section{INTRODUCTION}

Literacy shapes attitudes in writing writing and reading skills so that concepts that are embedded in students can be systematically conceptualized. Reading and writing activities are collaborative activities between writers and readers. The author will understand the text of the work based on what is read. While the reader will understand interpreting the writing of the knowledge that is read. It should be stressed that literacy does not mean that everyone who reads will write. Therefore, it needs to be bridged between literacy literacy and the reproduction of science. The process of the author is carried out many times to process the knowledge obtained from other sources obtained from reading then poured in writing. It is clear that reading has a close relationship with writing where it will determine the quality of someone's writing. The process of writing in school can be done in learning activities that are in accordance with the curriculum used in every level of education. 2013 curriculum, writing activities are always accompanied by reading activities so that it indirectly shapes literacy in students.

The 2013 curriculum in Indonesian language learning is directed at improving students' ability to think critically. This curriculum requires that learning Indonesian is not sakadar using Indonesian to deliver learning material, but must learn the meaning and selection of the right words. Indonesian language learning competency standards serve as a measure of students' ability to describe mastery of language knowledge and skills. In this curriculum, Indonesian language learning is text based. Text is interpreted as a unit of language that 
expresses meaning contextually. Text can be either written text or oral text which is an expression of the human mind. The more types of text mastered by students, the more the structure of thinking that can be used in social and academic life. Therefore, Indonesian language learning requires skilled students to communicate both orally and in writing. The more skilled a person speaks, the brighter and clearer the thinking.

In the 2013 curriculum in Indonesian language lessons, there was a change in the terms used in the teaching and learning process. The term change is found in the word producing. In the previous curriculum, the term used was writing. The term used is different but has the same purpose. [1] Producing is an activity to produce or issue results in the form of writing. The application of producing this in learning is making or writing a good and correct writing that aims to train students' abilities in writing.

One form of writing skills that must be mastered by students is to write explanatory texts. Students who sit in high school should be able to write explanatory texts. Writing explanatory text is an activity to write about the process of occurring natural and social phenomena. Then in writing explanatory texts, students are required to understand the structure and language of the explanatory text he will write. [2] One of the causes behind the students is not yet skilled in writing as follows. First, students tend not to pay attention to the structure and language of the explanatory text in writing. Secondly, students are weak in writing explanatory texts because students have difficulty communicating the material into written form. Third, it is difficult for students to develop ideas in written form. Fourth, students are still not able to make effective sentences and use punctuation that is not right.

\section{RESEARCH METHOD}

This type of research is quantitative research. Quantitative because the data to be collected is in the form of numbers and analysis using statistical formulas. This is in accordance with the opinion of [3], that quantitative research is a study whose research data is in the form of numbers and analysis using statistics. In this study, the research data came from the score of the influence of collaborative writing techniques on the ability to write explanatory texts. The research method used is the experimental method type pre-experimental design. According to [3], experimental research of the type of pre-experimental design has not been a real experiment, because there are still external variables that influence the formation of the dependent variable. So the experimental results which are the dependent variables are not solely influenced by independent variables. This can happen, because there is no control variable. [10] The reason for using the experimental method is because you want to know the effect of the treatment of collaborative writing techniques on the ability to write explanatory text.

\section{RESULT AND DISCUSSION}

\subsection{Writing the Student Explanation Text Before Using Collaborative Writing Techniques}

The steps taken to analyze the data in this study are as follows. First, analyze the ability to write explanatory text before using the technique of collaborative writing. Second, analyze the ability to write explanatory texts after using collaborative writing techniques. Third, see the presence or absence of the influence of collaborative writing techniques on the ability to write 
explanatory texts. For more details about the level of mastery in writing explanatory texts before using the technique of collaborative writing and after using the technique of collaborative writing.

The ability to write explanatory texts before using collaborative writing techniques was analyzed based on each learning indicator. Analyzing data based on indicators of learning and assessment of data on students' writing ability based on assessment indicators. Each indicator is given a score. The highest score gets a score of 3 and the lowest gets a score 1. Based on table 6 which has been described it can be seen the value of the ability to write explanatory text before using the technique of collaborative writing. Scores are obtained from the results of analyzing the data, then changed in value. The calculation of the value of the ability to write explanatory texts is based on the percentage formula. This value is interpreted into a scale conversion table 10. The overall value of writing explanatory text of students can be seen in table 1 below.

Table 1. Distribution of Frequency Ability to Write Explanation Text Before Using Student Collaborative Writing Techniques

\begin{tabular}{cccc}
\hline No & X & F & FX \\
\hline 1 & 33,33 & 3 & 99,99 \\
2 & 40 & 3 & 120 \\
3 & 53,33 & 7 & 373,31 \\
4 & 60 & 5 & 300 \\
5 & 66,67 & 3 & 200,01 \\
6 & 73,33 & 4 & 293,32 \\
& & $\mathbf{2 5}$ & $\mathbf{1 3 8 6 , 6 3}$ \\
\hline
\end{tabular}

\subsection{Writing Student Explanation Text After Using Collaborative Writing Technique}

The ability to write explanatory text after using student collaborative writing techniques can be seen from the test analysis table writing explanatory text based on each assessment indicator. Analyzing data based on assessment indicators can be explained as follows. Each indicator is given a value. The highest score gets a score of 3 and the lowest gets a score of 1 . Based on the table that has been described, it can be seen the value of the ability to write explanatory text after using students' collaborative writing techniques. Scores are obtained from the results of data descriptions, then changed in the form of values. The calculation of the value of the ability to write explanatory texts is based on the percentage formula. The overall value of explanatory text writing ability of students can be seen in table 2 below. 
Table 2. Distribution of Frequency Ability to Write Explanatory Text After Using Collaborative Writing Techniques

\begin{tabular}{cccc}
\hline No & $\mathbf{X}$ & $\mathbf{F}$ & $\mathbf{F X}$ \\
\hline 1 & 53,33 & 1 & 53,33 \\
2 & 60 & 4 & 240 \\
3 & 66,67 & 2 & 133,34 \\
4 & 73,33 & 3 & 219,99 \\
5 & 80 & 4 & 320 \\
6 & 86,67 & 6 & 520,02 \\
7 & 93,33 & 5 & 466,65 \\
Sum & & $\mathbf{2 5}$ & $\mathbf{1 9 5 3 , 3 3}$ \\
\hline
\end{tabular}

\subsection{Test Data Analysis Requirements}

Based on the ability to write explanatory texts before and after using student collaborative writing techniques, there are also test requirements for data analysis divided into two as follows. First, the data normality test is done to find out whether the data is normally distributed or not. The normality test of the data is done by liliefors test. Based on the tests performed, L0 and Lt were obtained at a significant level of 0.05 for $\mathrm{n}=25$, as in the following table.

Table 3. Data Normality Test

\begin{tabular}{clllccc}
\hline No. & (N) & $\begin{array}{c}\text { Sum } \\
(\mathbf{N})\end{array}$ & Real Level & Lo & Lt & Light \\
\hline 1 & Pretest & 25 & 0,05 & 0,1249 & 0,173 & Normal Distribution \\
2 & Posttest & 25 & 0,05 & 0,1222 & 0,173 & $\begin{array}{c}\text { Normal } \\
\text { Distribution }\end{array}$ \\
\hline
\end{tabular}

Based on the table above, it can be concluded that the data are normally distributed at the 0.05 level, for $n=25$ because $L_{0}$ is smaller than $L_{t}$. Data homogeneity test was conducted to find out whether the data of the two sample groups had homogeneity or not. This data homogeneity test is done with the comparison formula of the largest variant with the smallest variant. Based on the homogeneity test conducted, obtained $F_{\text {count }}$ and $F_{\text {table }}$ at the 0.05 significance level for $\mathrm{N}=25$, as in the following table.

Table 4. Data Homogeneity Test

\begin{tabular}{ccccccc}
\hline No. & $\mathbf{N}$ & $\mathbf{N}$ & Real Level & $\boldsymbol{F}_{\text {count }}$ & $\boldsymbol{F}_{\text {table }}$ & Light \\
& & $(\mathbf{N})$ & $(\mathbf{N})$ & & & \\
\hline 1 & Pretest & 25 & 0,05 & & & \\
2 & Posttest & 25 & 0,05 & 1,02 & 1,98 & Homogen \\
\hline
\end{tabular}

Based on the table, it was concluded that the data of the two sample groups had homogen at a significant level of 0.05 for the numerator $\mathrm{dk}=\mathrm{n}-1=25-1=24$ and for the denominator $\mathrm{n}-1=25-1=24$ because $\mathrm{F}_{\text {coun }} \mathrm{t}<\mathrm{F}_{\text {table }}(1,20<1.98)$. Based on the research and data processing carried out above, students' writing skills will be made if reading skills are often possible. 
Knowledge will be accumulated based on reading activities, writing will play a role in expressing ideas, opinions (knowledge in writing or work. Using collaborative writing techniques in powerful spell bidding writing activities for writing activities for students. This writing activity is done in writing explanatory texts. students have a large influence on writing activities carried out by students.

Disciplinary learning is learning that integrates knowledge and perceptions of existing phenomena. For example, knowledge is a process that is formed by a scientific method, while technology is a form of something formed. With the disciplinary learning process able to integrate knowledge and technology used in the learning process in the era of technology age, educators are required to master technology as forming learning activities in schools in accordance with the criculum used, namely the 2013 curriculum.

Implementation of writing learning will be seen from reading activities carried out by students. Literacy which is the process of learning to read and write requires high motivation and motivation. Therefore, reading and writing is a disciplinary learning that can shape creativity in students in literacy so that students can grow willingness to read and write. In learning Indonesian literacy activities are not only enough to be done for 15 minutes in the learning process, but require extra guidance. The culture of reading and writing has been formed since it was written in addition to the literacy culture that can be integrated in the activities of using methods, class mastery strategies. Learning in schools is not a sacrament to see the abilities of students, but also shapes the character of the students. Discipline learning does not provide learning with the use of other sciences such as technology in providing learning material, but can shape the character in students.

\section{CONCLUSIONS}

Based on the research findings and the discussion of the ability to write explanatory texts three conclusions were obtained. First, the ability to write explanatory texts before using collaborative writing techniques is 55.46 with almost moderate qualifications in the range of 46-55\%. Second, the ability to write explanatory texts after using collaborative writing techniques is 78.13 qualifying well at a range of $76-85 \%$. Third, there is a significant influence on the use of collaborative writing techniques on the ability to write explanatory texts. This is evidenced by the results of research that show that the value of tcount (5.74) $>t$ table (1.71), so that $\mathrm{H} 0$ is rejected and $\mathrm{H} 1$ is accepted.

With the results of the above research that the hypothesis is accepted, it can be interpreted by using collaboration writing in the writing process, students can help the process of students' creativity in writing according to the stage of writing activities. The four-dimensional writing activity is literary, linguistic language), cognitive, sociocultural and the focus of affective development. Writing is an important part of teaching and learning where the reproductive process of science is more developed. With collaborative writing in writing activities can help students in writing so that there will be feedback in the learning process

\section{REFERENCES}

[1] K. Anggraeni, "EFEKTIVITAS MODEL MENULIS KOLABORASI DENGAN MEDIA BIG BOOK TERHADAP KETERAMPILAN MENULIS KREATIF", Cakrawala Pendas, vol 3, no 2, bll 1-10, 2017.

[2] D. Darmawangsa, "MELALUI BLOG UNTUK MENINGKATKAN 
KETERAMPILAN", vol 1, 2014.

[3] Sugiyono. 2010. Metode Penelitian Kuantitatif dan Kualitatif dan R\&D. Bandung: Alfabeta.

[4] Alwasilah, A. Chaedar dan Alwasilah, Senny Suzanna. 2005. Pokoknya Menulis. Bandung: PT Kiblat Buku Utama.

[5] Arikunto, Suharsimi. 2012. Prosedur Penelitian: suatu pendekatan praktik. Jakarta: Rineka Cipta.

[6] Barkley, Elizabert E dkk. 2016. Collaborative Learning Techniques. Bandung: Nusa Media.

[7] Handayani dan Kumara. 2016. Implementasi Collaborative Writing Sebagai Upaya Peningkatan Kemampuan Mahasiswa (Calon Guru) dalam Menyusun RPP Kurikulum 2013. Santiaji Pendidikan, Volume 1, Nomor 2, Halaman 8, Universitas Mahasaraswati Denpasar.

[8] Hulpa, Widia Nurul dkk. Penerapan Metode ESCO (Estafet Writing and Collaborative Writing) dengan Media Gambar untuk Meningkatkan Kemampuan Melengkapi Cerita Rumpang. Jurnal Pena Ilmiah. Volume 1, Nomor 1, Halaman 744, UPI Kampus Sumedang.

[9] Lee, L. (2010). Exploring wiki-media collaborative writing: A Case Study in an Elementary Spanish Course. CALICO Journal, 27(2), 260-276.

[10] Storch, N. (2005). Collaborative writing: Product, process, and students' reflections. Journal of Second Language Writing, 14(3), 153-173. 